\title{
SURVEI TENTANG MOTIVASI ORANG TUA MENGIKUTSERTAKAN ANAKNYA DI MATARAM SOCCER ACADEMY TAHUN 2019
}

\author{
Soemardiawan ${ }^{1}$, Ismail Marzuki ${ }^{2}$ \\ ${ }^{1}$ Fakultas Ilmu Keolahragaan Dan Kesehatan Masyarakat, UNDIKMA (Soemardiawan) \\ Email: umanksoemardiawan84@gmail.com \\ ${ }^{2}$ Fakultas Ilmu Keolahragaan Dan Kesehatan Masyarakat, UNDIKMA (Ismail Marzuki) \\ Email: ismailmarzuki@ikipmataram.ac.id
}

\begin{abstract}
This research aims to know the motivation of parents to include their children in Mataram Soccer Academy., IN Mataram. This research was conducted in Mataram Soccer Academy.field, GOR Turida Mataram from December $2^{\text {th }}$ to December $9^{\text {nd }} 2019$. This research used descriptive method by using survey technique in the form of questionnaire. The sampling technique was taken from 60 parent's samples who involve their children in Mataram Soccer Academy City Mataram. The instruments used were questionnaires and Likert Scale for choice category. The testing of instrument validity used Product Moment for motivation variable. The reliability for variable motivation used Alpha Cronbach formula. The research result showed that the highest motivation of parents to involve their children to Mataram Soccer Academy city Mataram is motivated by the factor of appreciation needs by $29 \%$. Therefore, the appreciation factor is the important thing for parents to involve their children to the academy.
\end{abstract}

Key words: Survey, Parents' Motivation, Mataram Soccer Academy

\section{Abstrak}

Penelitian ini bertujuan untuk mengetahui motivasi orang tua mengikutsertakan anaknya di Mataram Soccer Academy. Penelitian ini dilaksanakan di lapangan GOR Turida Mataram, pada tanggal 2 Desember s/d 9 2019. Penelitian ini menggunakan metode deskriptif dengan teknik survey dalam bentuk angket. Teknik pengambilan sampel diambil 60 sampel orang tua yang mengikutsertakan anaknya di Mataram Soccer Academy di Mataram. Instrumen yang digunakan adalah instrumen kuesioner dan Skala Likert untuk kategori pilihan. Pengujian validitas instrumen menggunakan Product Moment untuk variabel motivasi. Reliabilitas untuk variabel motivasi menggunakan rumus Alpha Cronbach. Hasil penelitian menunjukkan bahwa motivasi orang tua mengikutsertakan anaknya ke Mataram Soccer Academy Kota Mataram adalah yang tertinggi dilatarbelakangi oleh faktor kebutuhan penghargaan yakni sebesar 29\%. Oleh karena itu, faktor penghargaan merupakan hal yang penting bagi orang tua untuk mendaftarkan anaknya ke Mataram Soccer Academy ini.

Kata Kunci: Survei, Motivasi Orang Tua, Mataram Soccer Academy

\section{PENDAHULUAN}

Kemajuan permainan sepak bola di Indonesia juga dilihat dari mulai banyaknya pembinaan pemain sepak bola usia dini yang diwadahi oleh Sekolah Sepak Bola (SSB). Sekolah Sepak Bola adalah sekolah yang mempelajari tentang permainan sepak bola dan berfungsi mengembangkan potensi yang dimiliki atlet serta menjadi wadah pembinaan

Jurnal Pendidikan Mandala sepak bola usia dini. SSB juga memberikan dasar yang kuat tentang cara bermain sepak bola yang benar, termasuk membentuk sikap, kepribadian, mental, dan perilaku yang baik, sedangkan prestasi merupakan tujuan jangka panjang mereka. Mengingat banyaknya minat masyarakat terhadap olahraga sepak bola dan makin menjamurnya fasilitas olahraga sepak bola sebagai peluang bisnis yang menjanjikan 
dan dengan banyaknya fasilitas olahraga sepak bola, maka, secara otomatis makin banyak pula klub atau Sekolah Sepak Bola yang mulai berkembang.

Pembahasan di atas lebih baik lagi mendapatkan dukungan atau partisipasi sepenuhnya dari orang tua, karena merekalah yang akan memberikan pengaruh positif terhadap hasil pembinaan dan pendidikan anaknya secara keseluruhan. Orang tua yang dimaksud disini adalah mereka yang turut bertanggung jawab terhadap pertumbuhan dan perkembangan anaknya. Dalam kegiatan olahraga, anak harus hidup disiplin, teratur, dan mandiri agar stamina serta kesehatannya tetap terjaga. Pada akhirnya, perkembangan anak akan terlihat dan mendapatkan prestasi yang baik. Sebagian besar orang tua pasti menginginkan anaknya menjadi generasi penerus keluarga dan menjadi manusia yang terampil, cerdas, berkepribadian baik serta memiliki kepercayaan pada diri sendiri. Maka dari itu, orang tua harus lebih selektif dalam mengarahkan anaknya pada suatu kegiatan dan pada kenyataannya sekarang, tidak sedikit para orang tua yang mengikutsertakan anaknya untuk masuk ke cabang olahraga sepak bola yang menjanjikan penumbuhan sikap yang baik terhadap pemainnya.

Hal ini disambut baik dengan makin maraknya pembinaan sepak bola usia dini melalui Sekolah Sepak Bola. Salah satu contoh Sekolah Mataram Socer Academy Sekolah Sepak Bola ini berlokasi di stadion Gor Turide, kota Mataram. Mataram Socer Academy ini memiliki 200 siswa. Banyaknya siswa tersebut dapat menjadi ukuran bahwa banyak anak yang ingin mendalami permainan olahraga cabang sepak bola sejak dini melalui SSB. Berhasil atau tidaknya suatu proses pembelajaran olahraga sepak bola ini tentu dilatarbelakangi oleh banyak faktor, baik itu faktor internal, maupun eksternal. Faktor internal bisa meliputi pelatih, fasilitas, dan kemauan dari dalam diri anak tersebut. Sedangkan faktor eksternal mencakup keluarga, lingkungan, teman, dan masyarakat.
Melihat banyaknya anggota di Sekolah Mataram Socer Academy di Mataram, maka timbul pertanyaan, motivasi apa yang melatar belakangi para orang tua murid memilih olahraga sepak bola, sementara dilihat dari segi waktu, mungkin saja kegiatan ini akan mengganggu istirahat dan pekerjaan rumah anak mereka. Selain itu, dari segi materi, para orang tua sudah pasti mengeluarkan biaya yang cukup besar untuk mengikutsertakan anaknya di Sekolah Sepak Bola, hal demikian terlihat dengan biaya setiap bulan bisa mencapai ratusan ribu. Apabila setiap orang tua mempunyai anak lebih dari satu, maka biaya yang akan dikeluarkan lebih besar. Bukan hanya hal tersebut, kendala lain juga terlihat di beberapa Sekolah Sepak Bola, yaitu, sebagian siswa ada yang tiba-tiba menghilang begitu saja setelah beberapa kali latihan karena merasa sudah memiliki skill dalam sepak bola atau terkadang juga faktor jadwal yang sibuk maupun kelelahan sehingga mulai jarang datang untuk latihan.

Hal ini terkadang mereka lakukan tanpa mempertimbangkan biaya dan harapan yang sudah dikeluarkan oleh orang tua mereka. Banyaknya tantangan dalam mengikutsertakan anaknya ke Sekolah Sepak Bola, menjadi hal yang sangat menarik untuk diteliti ditengah waktu kegiatan mereka yang cukup padat. Keadaan tersebut menjadi fenomena yang menarik yang akan menjawab, motivasi apa yang melatarbelakangi orang tua mengikutsertakan anaknya di Sekolah Sepak Bola.

\section{KAJIAN PUSTAKA}

\section{Motivasi}

Kata "motif", diartikan sebagai daya upaya yang mendorong seseorang untuk melakukan sesuatu. Motif dapat dikatakan sebagai daya penggerak dari dalam dan di dalam subjek untuk melakukan aktivitasaktivitas tertentu demi mencapai suatu tujuan. Bahkan motif dapat diartikan sebagai suatu kondisi intern (kesiapsiagaan). Berawal dari kata "motif" itu, maka motivasi dapat diartikan sebagai daya penggerak yang telah menjadi 
aktif. Motif menjadi aktif pada saat-saat tertentu, terutama bila kebutuhan untuk mencapai tujuan sangat dirasakan/mendesak. Sardiman, (20114:73). Motif merupakan dorongan yang berasal dari dalam atau dari luar individu untuk melakukan suatu aktivitas yang bisa menjamin kelangsungan aktivitas tersebut, serta dapat menentukan arah, haluan dan besaran upaya yang dikerahkan untuk melakukan aktivitas sehingga dapat mencapai tujuan yang telah ditetapkan, Komarudin, (2013:24). Sejalan dengan arti di atas, Bimo Walgito, (2004:149.) dalam bukunya juga menjabarkan, "Motif sebagai sesuatu kekuatan yang terdapat dalam diri organisme yang menyebabkan organisme itu bertindak atau berbuat sesuatu".

Motivasi ada dua, yaitu motivasi intrinsik dan motivasi ekstrinsik. Motivasi intriksik adalah jenis motivasi ini timbul dari dalam diri individu sendiri tanpa ada paksaan dan dorongan dari orang lain, namun atas dasar kemauannya sendiri. Sedangkan motivasi ekstrinsik adalah jenis motivasi ini timbul sebagai akibat pengaruh dari luar individu, apakah karena adanya ajakan, suruhan, atau paksaan dari orang lain, sehingga dengan keadaan demikian anak mau melakukan sesuatu atau belajar., Fita Nur Arifah, (2016). Sedangkan motivasi ekstrinsik adalah dorongan yang berasal dari luar diri individu yang menyebabkan individu berpartisipasi dalam melakukan aktifitas tersebut. Dorongan ini bisa berasal dari pelatih, orang tua atau pemberian hadiah berupa sertifikat, medali ataupun berbentuk bonus atau uang. Motivasi ekstrinsik dapat dipelajari dari besarnya nilai penguat itu. Walaupun motivasi ini kurang efektif dibandingkan dengan motivasi instrinsik, namun bila tidak ada motivasi instrinsik, maka pelatih, orang tua, maupun pembina dapat menumbuhkan motivasi ekstrinsik. Salah seorang tokoh yang menjadi pelopor teori motivasi adalah Abraham $H$. Maslow yang menuangkan hasil pemikirannya dalam buku yang berjudul Motivation and Personality. Keseluruhan teori motivasi yang dikembangkan
Maslow berintikan pendapat yang mengatakan bahwa kebutuhan manusia itu dapat diklasifikasi menjadi lima hirarkhi kebutuhan, yaitu:

1. Kebutuhan fisiologis,

2. Kebutuhan akan keamanan,

3. Kebutuhan rasa kasih sayang (sosial),

4. Kebutuhan esteem (penghargaan),

5. Kebutuhan untuk aktualisasi diri.

\section{Sepakbola}

Sepak bola adalah permainan beregu yang dimainkan oleh dua regu, yaitu masingmasing regunya terdiri atas sebelas pemain termasuk seorang penjaga gawang. Permainan sepak bola dilakukan dengan seluruh anggota badan kecuali dengan kedua lengan tangan (Sukatamsi, 1997: 28). Permainan olahraga sepak bola merupakan cabang olahraga beregu. Untuk memenangkan pertandingan setiap regu berusaha memasukkan bola ke gawang lawan sebanyak-banyaknya dan berusaha mempertahankan gawangnya agar tidak dapat dimasukkan oleh tim lawan. Pemain sepak bola harus dapat memiliki bekal yang baik agar dapat bermain dengan baik. Penguasaan teknik dan taktik serta didukung dengan keadaan fisik bisa membuat pemain sepak bola dapat bermain secara maksimal.Tantangan fisik dan mental yang dihadapi pemain benar-benar luar biasa. Keberhasilan tim dan keberhasilan individu dalam bermain sepak bola akhirnya tergantung sepenuhnya pada kemampuan pemain dalam menghadapi tantangan dalam pertandingan sepak bola. Kemampuan demikian perlu dikembangkan melalui latihan.

Teknik dasar bermain sepak bola adalah semua gerakan-gerakan tanpa bola dan gerakan-gerakan dengan bola yang diperlukan untuk bermain sepak bola. Jadi, teknik dasar bermain sepak bola adalah merupakan kemampuan untuk melakukan gerakan-gerakan atau mengerjakan sesuatu yang terlepas sama sekali dari permainan sepak bola. Sedangkan keterampilan teknik bermain sepak bola (skill) adalah penerapan teknik dasar permainan sepak bola dalam bermain sepak bola. Dari pendapat para ahli di atas dapat disimpulkan bahwa 
permainan olahraga sepak bola merupakan permainan beregu yang dilakukan oleh sebelas orang dalam setiap regu sudah termasuk penjaga gawang. Permainan sepak bola bertujuan untuk memasukkan bola ke gawang lawan sebanyak-banyaknya dan berusaha menjaga gawangnya agar tidak kebobolan oleh tim lawan. Permainan ini dilakukan oleh seluruh anggota badan kecuali kedua tangan, sedangkan untuk posisi penjaga gawang boleh melakukannya dengan seluruh anggota badan.

\section{Mataram Soccer Academy}

Sekolah sepak bola adalah suatu bakat atau hobi untuk menyalurkan bakat dalam bermain sepak bola sejak usia dini. Di dalam sekolah sepak bola mayoritas pemainnya masih berusia relatif muda. Fokus pembinaan usia muda adalah mencetak pemain berkualitas dan profesional. Sepakbola kini bukanlah hanya sebagai pemenuhan kebutuhan olah raga, melainkan telah menjadi sebuah profesi dengan prestasi yang patut untuk dibanggakan. memasyarakatnya permainan sepakbola ini telah menjadikannya sebagai salah satu cabang olah raga yang paling diminati dan paling terus berkembang, tidak heran jika hampir seluruh negara di dunia ini berlomba-lomba untuk menggalang prestasi mengagumkan untuk jenis olah raga ini. Indonesia sebagai negara yang sedang berkembang juga berupaya untuk menggalang prstasi di bidang olah raga sepak bola. Semakin bertambahnya jumlah kompetisi intern maupun turnamen dalam rangka mencari pemain berbakat, menjadikan sepakbola sebagai salah satu olah raga yang popular dan berpotensi untuk dikembangkan.

Hal inilah yang kemudian mengakibatkan semakin meningkatnya masyarakat Indonesia yang menjadikan sepak bola sebagai profesi hidup. Dengan adanya motivasi pemain sepak bola agar menjadi pemain yang berkualitas, maka di adakan suatu sekolah sepak bola. Hal ini dikarenakan sekolah sepak bola dapat membentuk seorang anak untuk menjadi atlit sepakbola yang profesional. Sekolah sepakbola merupakan program pengembangan sejak usia dini. Oleh karena itu, dengan adanya sekolah sepakbola dapat membantu anak-anak dalam menekuni cabang olah raga sepakbola sejak usia dini guna tercapainya suatu prestasi yang menggembirakan di cabang olah raga sepak bola. Mataram Socer Academy berdiri sejak 11 November 2015 dan MSA ini merupakan salah satu Sepakbola yang berada diKota Mataram. MSA ini terletak di stadion Gor turide, Jalan Peserta didik di Mataram Socer Academy berjumlah 200 siswa yang dibagi menjadi beberapa kategori usia, yaitu antara usia 7 sampai 16 tahun.

Berdasarkan hal tersebut, maka timbul suatu permasalahan yang perlu diangkat dalam suatu penelitian yang berkaitan dengan motivasi orang tua mengikutsertakan anaknya ke Mataram Socer Academy sebagai sampel penelitian. Oleh karena itu, peneliti berusaha mencari fakta yang ada di lapangan untuk dapat diambil kesimpulan terhadap seberapa besar motivasi orang tua memasukkan puteranya ke Mataram Socer Academy di Mataram. Motivasi orang tua mengikutsertakan anaknya di sekolah sepakbola mempunyai tujuan tertentu yang diinginkan. Tujuannya adalah bagi orang tua itu sendiri sebagai sarana rekreasi setelah bekerja dalam keseharian, sehingga dapat mengembalikan semangat dan kesegaran tubuhnya baik fisik maupun psikisnya. Sedangkan untuk anak dengan bermain sepakbola adalah untuk mengisi waktu luang setelah menghabiskan waktunya disekolah. Dalam artian ini sepakbola dijadikan sebagai sarana refreshing bagi anak-anak. Kemudian sepakbola juga bisa meningkatkan keterampilan, memperkaya pengetahuan anak juga mendorong nilai dari sikap sportif dan mudah-mudahan dapat mampu meningkatkan prestasi.

Hubungan motivasi orang tua mengikutsertakan anaknya di sekolah sepakbola dengan ke lima kebutuhan manusia menurut Hierarki Maslow :

1. Hubungan motivasi orang tua dengan kebutuhan fisiologis. 
Kebutuhan ini dapat bersifat biologis yang hubungannya dengan kesehatan adalah setiap orang tua mengantarkan anaknya ke sekolah sepakbola sebagai sarana untuk meningkatkan kebutuhan fisik anaknya melalui salah satu cabang olahraga yaitu sepak bola .

2. Hubungan motivasi orang tua dengan kebutuhan rasa aman.

Orang tua merasa dirinya aman karena anaknya dapat menggunakan waktunya dengan baik dan tidak digunakan dengan kegiatan yang tidak baik dengan temanteman sebayanya serta anak dalam belajar pun akan tenang karena ada pengawasan secara langsung dari pelatihnya dan dapat dipertanggung jawabkan.

3. Hubungan motivasi orang tua dengan kebutuhan kasih sayang.

Anak pada usia yang masih dini tentunya akan membutuhkan rasa kasih sayang dari orang tuanya. Orang tua atau pelatih dapat dijadikan sebagai teman dekatnya, tidak hanya rasa kasih sayang saja akan tetapi rasa cinta pada anak dapat diberikan. Biasanya anak dalam mengenal lingkungan baru, kejadian apa saja yang dialaminya akan diceritakan pada orang tua. Karena rasa sayang orang tua kepada anaknya tersebut orang tua berusaha untuk mendaftarkan anaknya kepada Sekolah Mataram Socer Academy tersebut untuk menyalurkan hobi serta melatih bakat anak.

4. Hubungan motivasi orang tua dengan kebutuhan penghargaan.

Pada dasarnya orang lebih senang dipuji atau disanjung begitu pula dengan setiap orang tua akan lebih senang apabila dirinya diperbincangkan oleh temantemannya karena berhasil dalam mendidik anaknya sehingga pengakuan dan penghargaan akan harga dirinya menjadi naik dan akan dihormati. Begitu pula dengan anak biasanya akan marah apabila dirinya dicaci atau dimaki hal ini berarti harga diri si anak tidak ingin disepelekan oleh teman-temannya. Kenyataan seperti inilah yang akan dicari jalan keluarnya agar harga diri anak tetap terjaga.

5. Hubungan motivasi orang tua dengan kebutuhan aktualisasi diri.

Pada usia anak-anak merupakan masa-masa pertumbuhan dan perkembangan, untuk itu bagaimana seharusnya menjadikan suatu kegiatan dan memperhatikan kegiatan aktualisasi diri anak bisa berkembang, pada akhirnya tidak merusak pada diri anaknya.

\section{METODE PENELITIAN}

\section{Rancangan kegiatan}

Penelitian ini menggunakan metode deskriptif ialah suatu metode dalam meneliti status sekelompok manusia, suatu objek, suatu set kondisi, suatu sistem pemikiran ataupun suatu kelas peristiwa pada masa sekarang. Tujuannya adalah untuk membuat deskriptif, gambaran atau lukisan secara sistematis, factual dan akurat mengenai fakta-fakta, sifat-sifat serta hubungan antarfenomena yang diselidiki, M. Nazir, (1998:63) Jenis penelitian ini menggunakan penelitian survey yang pelaksanaanya berdasarkan pengamatan. Penelitian di atas hanya menggambarkan variable yang diteliti dengan kondisi apapun. Seperti yang dijelaskan oleh Suharsimi Arikunto bahwa penelitian deskriptif merupakan tanpa hipotesis sehingga dalam langkah penelitiannya tidak diperlukan hipotesis.

\section{Ruang lingkup}

Ruang lingkup penelitian tentang survei tentang motivasi orang tua mengikutsertakan anaknya di mataram soccer academy tahun 2019, jadi objek penelitian adalah orang tua siswa tersebut. Mengingat luasnya Permasalahan dan dengan pertimbangan segala keterbatasan maka peneliti membatasi pada salah satu permasalahan yaitu

a) Subjek penelitian

Subjek penelitian adalah orang tua yang mengikutsertakan anaknya di mataram Soccer Academy.

b) Objek Penelitian 
Objek nya adalah survei tentang motivasi orang tua mengikutsertakan anaknya di mataram soccer academy tahun 209

\section{Bahan dan alat utama}

Instrumen untuk penelitian ini berbentuk angket atau kuesioner yang berisi beberapa pernyataan yang dilengkapi dengan sejumlah alternatif. Responden hanya memilih salah satu dari alternatif atau kategori pilihan jawaban yang sesuai dengan pilihannya, yaitu dengan cara memberikan jawaban tanda ceklis ( $\sqrt{ }$ ) pada kolom yang sudah disediakan. Pemberian nilai jawaban angket pada setiap pernyataan berdasarkan skala likert yang meliputi 5 kategori pilihan jawaban. Ditawarkan 5 pilihan jawaban ini, dimaksudkan agar responden tidak ragu-ragu dalam menjawab pernyataan, pemberian skor atau nilai untuk masing-masing jawaban adalah sebagai berikut:

\section{Tempat}

Penelitian ini dilaksanakan di lapangan Mataram Soccer Academy, Waktu Penelitian yang dijelaskan dan difokuskan pada pengambilan data yaitu dilaksanakan pada tanggal 2 Desember s/d 9 desember 2019, Gor Turide Kota Mataram.

\section{Teknik penumpulan data}

Adapun teknik pengumpulan data dalam penelitian ini adalah menggunakan angket atau kuesioner dengan daftar isian skala Likert, yaitu teknik pengumpulan data melalui pernyataan yang diberikan kepada responden. Kemudian angket atau kuesioner ini diberikan dan di isi oleh 60 orang tua yang mengikutsertakan anaknya di Sekolah Sepakbola Bina Taruna Jakarta. Untuk mengumpulkan data yang akan dianalisis menggunakan instrumen penelitian. Sesuai dengan metode yang akan digunakan, instrumen untuk penelitian ini berupa angket yaitu sejumlah pernyataan tertulis yang digunakan untuk memperoleh informasi dari responden. Angket ini bersifat berstruktur yaitu pertanyaan yang dibuat sedemikian rupa sehingga responden dibatasi dalam memberikan jawaban kepada beberapa alternatif saja ataupun kepada satu jawaban., M. Nazir,
(1998:250) Yang ditujukan kepada para orang tua yang mengikutsertakan anaknya dalam olahraga sepakbola di sekolah sepakbola Bina Taruna, yang akan menjadi sampel dalam penelitian ini

\begin{tabular}{|l|l|}
\multicolumn{1}{c|}{ Tabel 1. Kategori Jawaban Angket } \\
\hline Kategori Jawaban & Nilai Positif \\
\hline Sangat Setuju & 5 \\
Setuju & 4 \\
Ragu-ragu & 3 \\
Tidak Setuju & 2 \\
Sangat Tidak Setuju & 1 \\
\hline
\end{tabular}

Sebelum instrumen digunakan, terlebih dahulu diuji validitas dan reabilitasnya. Validitas menunjukkan sejauh mana suatu alat ukur mengukur apa yang ingin diukur. Reliabilitas mengacu sejauh mana suatu alat pengukur secara konsisten mengukur apa saja yang akan diukur.

\section{a. Penyusunan kisi-kisi}

Kisi-kisi angket motivasi orang tua mengikutsertakan anaknya di sekolah Mataram Soccer Academy.

\begin{tabular}{|l|l|l|}
\multicolumn{2}{|c|}{ Tabel 2. Kisi-kisi Instrumen Penelitian } \\
\hline VARIABEL & DIMENSI & NO.SOAL \\
\hline $\begin{array}{l}\text { Motivasi orang tua } \\
\text { mengikutsertakan } \\
\text { anaknya di Sekolah } \\
\begin{array}{l}\text { Sepakbola Bina } \\
\text { Taruna Jakarta }\end{array}\end{array}$ & 1. Kebutuhan Fisiologis & 5 \\
\cline { 2 - 4 } & $\begin{array}{l}\text { 2. Kebutuhan rasa aman dan } \\
\text { nyaman }\end{array}$ & $6,8,19$ \\
& 3. Kebutuhan social & $7,25,11,16$ \\
& & 12,15 \\
& & 13,21 \\
\cline { 2 - 4 } & 4. Kebutuhan penghargaan & $1,10,22$ \\
& & $17,20,33$ \\
& 5. Kebutuhan aktualisasi diri & $26,27,31$ \\
& & $3,24,30,32$ \\
\hline
\end{tabular}

\section{b. Kalibrasi}

Kalibrasi dilakukan dengan menganalisis data ujicoba kepada 30 orang tua murid di sekolah sepak bola cabang lain untuk menentukan validitas butir dan pengujian validitas menggunakan rumus produc momen correlation. Maka kriteria batas minimum pertanyaan yang diterima adalah $\mathrm{r}$-table $=0,361$ jika r-hitung > r-table maka butir pertanyaan dianggap valid dan sebaliknya jika r-hitung $<r$ - 
table maka butir pertanyaan dianggap tidak valid atau drop/tidak digunakan.

Berdasarkan perhitungan pengujian validitas dengan menggunakan rumus oleh Suharsimi Arikunto, 2010: 256sebagai berikut:

$$
r=\frac{\left(n \cdot \sum x y\right)-\left(\sum x\right)\left(\sum y\right)}{\sqrt{\left.\left[\left(n \cdot \sum x^{2}\right)-\left(\sum x\right)^{2}\right)\right]\left[\left(n \cdot \sum y^{2}\right)-\left(\sum y^{2}\right)\right]}}
$$

$r=$ koefisien korelasi least sguast metode

$x=$ jumlah skor dalam distribusi $x$

$y=$ jumlah skor dalam distribusi $y$

$x^{2}=$ jumlah kuadrat dari distribusi $x$

$y^{2}=$ jumlah kuadrat dari distribusi $y$

$x y=$ jumlah skor hasil kali $x$ dengan $y$

$n=$ jumlah sampel

Sedangkan untuk reliabilitas tes menggunakan rumus Alpha Cronbach yaitu:

$$
r_{11}=\left(\frac{k}{k-1}\right)\left(1-\frac{\sum \sigma_{b}^{2}}{\sigma_{1}^{2}}\right)
$$

Diketahui:

$r_{11}=$ Reliabilitas

$\sum \sigma_{b}^{2} \quad=$ Variansi butir

$\sigma_{1}^{2}=$ Variansi total

$k=$ Jumlah soal

\section{Difinisi operasional variable}

a) Motivasi

Dari beberapa pengertian di atas, dapat disimpulkan bahwa motif merupakan suatu pendorong dalam diri manusia yang menjadi alasan untuk melakukan sesuatu karena memiliki suatu tujuan tertentu. Dari beberapa pendapat di atas dapat ditarik suatu kesimpulan bahwa motif merupakan sumber penggerak atau daya yang mendorong tingkah laku individu dalam memenuhi kebutuhan. Sejak lahir manusia telah membawa motif - motif tertentu dalam dirinya yang akan digunakan untuk memenuhi kebutuhan-kebutuhannya, terutama kelangsungan hidupnya. Ini berarti ada motif yang bersifat alami dan yang dipelajari, karena dalam perkembangan selanjutnya, individu akan dipengaruhi oleh keadaan lingkungan.

b) Orang Tua

Ayah dan atau ibu seseorang anak, baik melaluihubungan biologis maupun social. Umunya orangtua memilik peran yang sangat penting dalam membesarkan anak, dan panggilan ayah atau ibu dapat diberikan untuk perempuan/laki yang bukan orang tua kandung dari seseorangyang mengisi peran itu.

c) Sepakbola

Permainan olahraga sepak bola merupakan cabang olahraga beregu. Untuk memenangkan pertandingan setiap regu berusaha memasukkan bola ke gawang lawan sebanyak-banyaknya dan berusaha mempertahankan gawangnya agar tidak dapat dimasukkan oleh tim lawan. Pemain sepak bola harus dapat memiliki bekal yang baik agar dapat bermain dengan baik. Penguasaan teknik dan taktik serta didukung dengan keadaan fisik bisa membuat pemain sepak bola dapat bermain secara maksimal.

\section{Teknik analisa data}

Teknik analisa data yang menggunakan daftar pertanyaan berdasarkan kisi-kisi instrument.

1. Menghitung skor jawaban dari hasil pengamatan pada setiap butir-butir pertanyaan.

2. Menginterprestasikan setiap jawaban dari setiap indikator.

3. Menginterprestasikan setiap jawaban dari setiap dimensi.

\section{HASIL DAN PEMBAHASAN}

Hasil Penelitian menunjukkan bahwa dimensi penghargaan merupakan faktor yang paling menonjol daripada faktor-faktor yang lainnya dari semua kategori dalam memotivasi orang tua mengikutsertakan anaknya Mataram Socer Academy di Mataram. Hal ini dapat dilihat dari hasil persentase setiap dimensi pernyataan berdasarkan jumlah rata-rata semua kategori tiap dimensi, sebagai berikut:

Tabel 1. Distribusi Jawaban Tentang Dimensi Kebutuhan Fisiologis

\begin{tabular}{|c|c|c|c|}
\hline Interval & Kategori & Frekuensi & Persentase \\
\hline $6-14$ & Rendah & 25 & $41.67 \%$ \\
\hline $15-22$ & Sedang & 29 & $48.33 \%$ \\
\hline $23-30$ & Tinggi & 6 & $10 \%$ \\
\hline \multicolumn{2}{|c|}{ Jumlah } & 60 & $100.00 \%$ \\
\hline
\end{tabular}


JUPE: Jurnal Pendidikan Mandala

http://ejournal.mandalanursa.org/index.php/JUPE/index

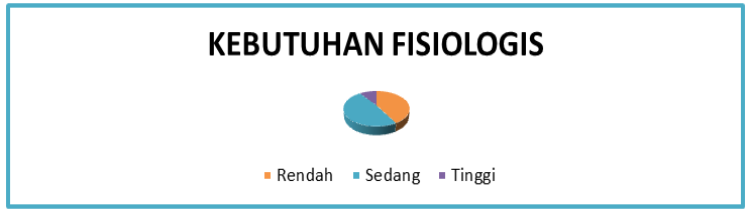

Gambar 1. Diagram Pie Persentase Dimensi Kebutuhan Fisiologis

|Tabel 2. Distribusi Jawaban Tentang Dimensi Kebutuhan Rasa Aman

\begin{tabular}{|c|c|c|c|}
\hline Interval & Kategori & Frekulensi & Persentase \\
\hline $6-14$ & Rendah & 0 & $0 \%$ \\
\hline $15-22$ & Sedang & 30 & $50 \%$ \\
\hline $23-30$ & Tinggi & 30 & $50 \%$ \\
\hline \multicolumn{2}{|c|}{ Jumlah } & 60 & $100 \%$ \\
\hline
\end{tabular}

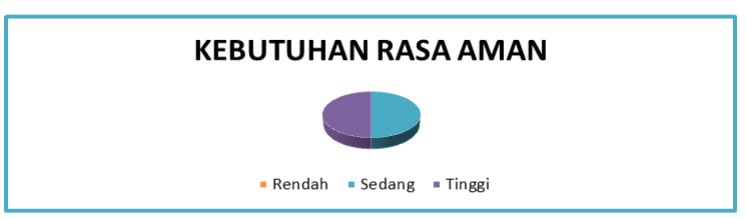

Gambar 2. Diagram Pie Persentase Dimensi Kebutuhan Rasa Aman

\begin{tabular}{|}
\hline Tabel 3. Distribusi Jawaban Tentang Dimensi Kebutuhan Sosial \\
\hline Interval & Kategori & Frekuensi & Persentase \\
\hline $7-16$ & Rendah & 0 & $0 \%$ \\
\hline $17-25$ & Sedang & 17 & $28.33 \%$ \\
\hline $26-35$ & Tinggi & 43 & $71.67 \%$ \\
\hline \multicolumn{3}{|c|}{ Jumlah } & 60 & $100 \%$ \\
\hline
\end{tabular}

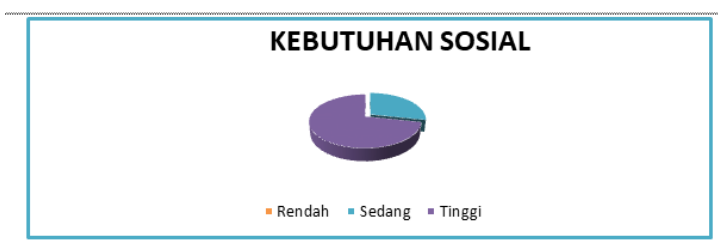

Gambar 3. Diagram Pie Persentase Dimensi Kebutuhan Sosial

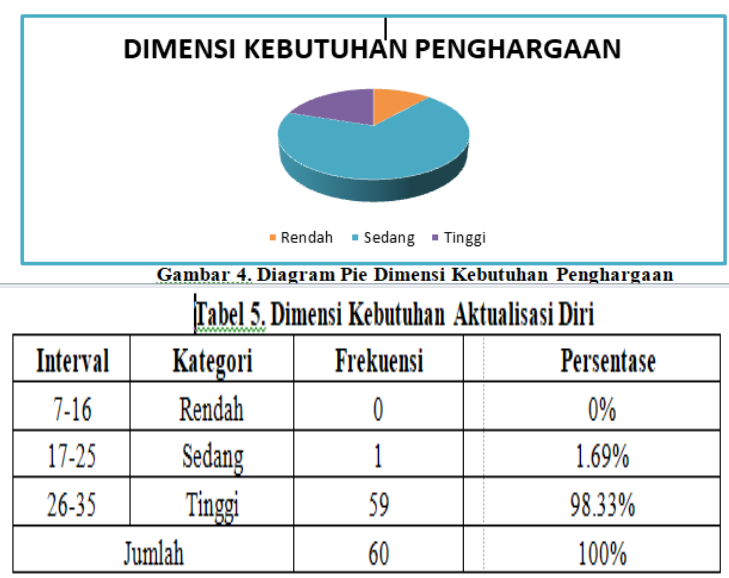

Vol. 4. No. 5 Desember 2019

p-ISSN: 2548-5555 e-ISSN:2656-6745

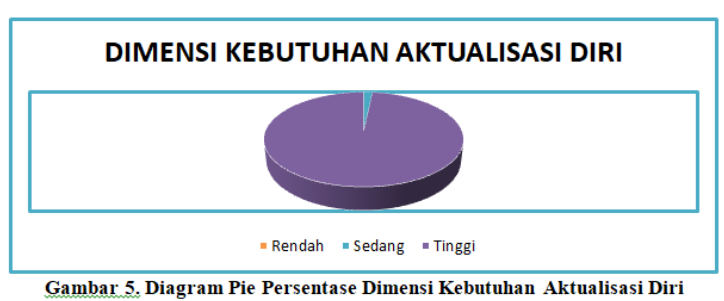

\begin{tabular}{l}
\hline \multicolumn{4}{|c|}{ Tabel 6. Distribusi Jawaban Tentang Persentase Variabel Motivasi Orang Tua } \\
\begin{tabular}{|l|l|c|c|}
\hline No. & Dimensi & Rerata Total Jawaban & Persentase \\
\hline $\mathbf{1}$ & Kebutuhan Fisiologis & 58 & $11 \%$ \\
\hline $\mathbf{2}$ & Kebutuhan Rasa Aman & 82 & $16 \%$ \\
\hline $\mathbf{3}$ & Kebutuhan Sosial & 113 & $21 \%$ \\
\hline $\mathbf{4}$ & Kebutuhan Penghargaan & 151 & $29 \%$ \\
\hline $\mathbf{5}$ & Kebutuhan Aktualisasi Diri & 123 & $23 \%$ \\
\hline Total & 527 & $100 \%$ \\
\hline
\end{tabular}
\end{tabular}

Hasil rangkuman motivasi orang tua mengikutsertakan anaknya di Mataram Socer Academy di Mataram dari yang tertinggi:

1. Motivasi orang tua dilihat dari kebutuhan penghargaan mengikutsertakan anaknya di Sekolah Mataram Socer Academy di Mataram 29\%

2. Motivasi orang tua dilihat dari kebutuhan aktualisasi diri mengikutsertakan anaknya di Sekolah Mataram Socer Academy di Mataram 23\%

3. Motivasi orang tua dilihat dari kebutuhan sosial mengikutsertakan anaknya di Sekolah Sepak Bola Mataram Socer Academy di Mataram 21\%

4. Motivasi orang tua dilihat dari kebutuhan rasa aman mengikutsertakan anaknya di Sekolah Sepak Bola Mataram Socer Academy di Mataram 16\%

5. Motivasi orang tua dilihat dari kebutuhan fisiologis mengikutsertakan anaknya di Sekolah Mataram Socer Academy di Mataram 11\%

Dibawah ini digambarkan grafik diagram batang dari persentase masing-masing dimensi motivasi orang tua yang mengikutsertakan anaknya di Sekolah Mataram Socer Academy di Mataram. 


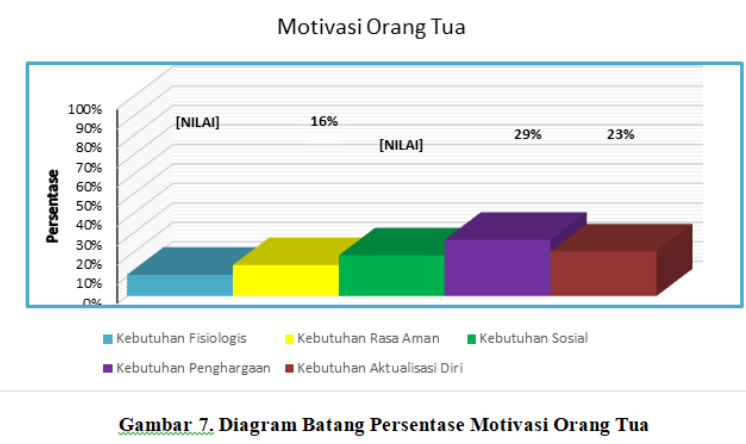

KESIMPULAN

Berdasarkan perumusan masalah yang telah dikemukakan dengan didukung deksripsi teoritis dan kerangka berpikir serta hasil analisis data yang telah diuraikan, maka hasil penelitian ini dapat disimpulkan sebagai berikut: Motivasi Orang Tua mengikutsertakan anaknya di Sekolah Mataram Socer Academy di Mataram adalah yang paling tinggi dilatarbelakangi oleh Faktor Kebutuhan Penghargaan yakni sebesar $29 \%$ dari semua dimensi yakni kebutuhan fisiologis sebesar $11 \%$, kebutuhan rasa aman sebesar $16 \%$, kebutuhan sosial sebesar $21 \%$, dan kebutuhan aktualisasi diri sebesar $23 \%$.

\section{SARAN}

Berdasarkan hasil penelitian di atas, maka penulis dapat memberikan saran:

1. Setiap orang tua yang mengikutsertakan anaknya di Sekolah Mataram Socer Academy di Mataram sebaiknya menyadari manfaat olahraga yang teratur terutama sepak bola di sela-sela kesibukan seharihari agar dapat menjaga dan meningkatkan kesehatan jasmani dan rohani.

2. Setiap orang tua sebaiknya ikut berperan dalam dalam pencapaian hasil latihan anak terutama diluar proses latihan anak seperti memperhatikan kondisi anak, memenuhi kebutuhan anak sehari-hari, makan, minum, istirahat, dan tidur yang teratur, nutrisi serta kebutuhan vitamin anak.

3. Pihak Sekolah Mataram Socer Academy di Mataram sebaiknya meningkatkan fasilitas serta pelayanan penerimaan siswa baru, meningkatkan program latihan, target prestasi yang ingin dicapai, serta sering melakukan evaluasi setiap kali melakukan latihan.

\section{REFRENSI}

Arikunto, S. 2002, Prosedur Penelitian Suatu Pendekatan Praktek, Jakarta:

Bimo Walgito, 2004. Pengantar Psikologi Umum. Yogyakarta: Andi Offset.

Fita Nur Arifah, 2016. Menjadi Guru Teladan,Kreatif,Inspiratif,Motivatif dan Profesional Yogyakarta: Araska.

http://bee89princess.blogspot.com/2012/03/kep erawatan-kebutuhandasarmanusia.html

http://digilib.unimus.ac.id/files/disk1/104/jtptun imus-gdl-eskasusiri-5185-3bab2.pdf

http://file.upi.edu/Direktori/FIP/JUR._PSIKOL OGI/195009011981032

RAHAYU_GININTASASI/MOTIF _SOSIAL.pdf

http://www.e-jurnal.com/2013/10/pengertianmotivasi.html

http://www.jawapos.com/read/2016/07/24/4102 4/indonesia-u-15-juara-duniakemenpora-inilah-talenta-indonesia

Komarudin, 2013. Psikologi Olahraga. Bandung: PT Remaja Rosdakarya.

M. Nazir,2014. Metode Penelitian. Jakarta : Graha Indonesia, 1998

Sardiman A.M, Interaksi dan Motivasi Belajar Mengajar, Jakarta: PT RajaGrafindo Persada. 